$$
\begin{aligned}
& \text { SANO98.0250C } \\
& \text { SAND- } 98-0250 C \\
& \text { CONF- } 980620-
\end{aligned}
$$

\title{
Site-Specific Thermal and Mechanical Property \\ Characterizations of In Situ Thermal Test Areas at Yucca \\ Mountain, Nevada
}

Nancy S. Brodsky, Glenn Barker, and Laurence Costin

Sandia National Laboratories ${ }^{1}$

Albuquerque, New Mexico USA
RECEIVED

JUI 301998

OSTI

\section{ABSTRACT}

The U.S. Department of Energy (DOE) is investigating Yucca Mountain, Nevada as a potential site for the disposal of high-level nuclear waste. The site is located near the southwest comer of the Nevada Test Site (NTS) in southern Nye County, Nevada. The underground Exploratory Studies Facility (ESF) tunnel traverses part of the proposed repository block. Alcove 5, located within the ESF is being used to field two in situ ESF thermal tests: the Single Heater Test (SHT) and the Drift Scale Test (DST). Laboratory test specimens were collected from three sites within. Alcove 5 including each in situ field test location and one additional site. The aim of the laboratory tests was to determine site-specific thermal and mechanical rock properties including thermal expansion, thermal conductivity, unconfined compressive strength, and elastic moduli. In this paper, the results obtained for the SHT and DST area characterizations are compared with data obtained from other locations at the proposed repository site. Results show that thermal expansion, and mechanical properties of Alcove 5 laboratory specimens are slightly different than the average values obtained on specimens from surface drillholes.

\section{KEYWORDS}

Yucca Mountain, tuff, thermal expansion, thermal conductivity, Strength, Young's modulus, Poisson's ratio

\section{INTRODUCTION}

The U.S. Department of Energy (DOE) is investigating Yucca Mountain, Nevada as a potential site for the disposal of high-level nuclear waste. The site is located near the southwest corner of the Nevada Test Site (NTS) in southern Nye County, Nevada. The underground Exploratory Studies Facility (ESF) tunnel traverses part of the proposed repository block. Alcove 5, located within the ESF is being used to field two in situ ESF thermal tests: the Single Heater Test (SHT) and the Drift Scale Test (DST). Laboratory test specimens were collected from three sites within Alcove 5 (each in situ field test location as well was one additional site) and one site within Alcove 7. Suites of mechanical and thermal properties tests were conducted on these specimens to provide unconfined compressive strengths, elastic moduli, thermal conductivities, and thermal expansion data. The laboratory methods

\footnotetext{
${ }^{1}$ Sandia is a multiprogram laboratory operated by Sandia Corporation, a Lockheed Martin Company, for the United States Department of Energy under Contract DE-ACO4-94AL85000 


\section{DISCLAIMER}

This report was prepared as an account of work sponsored by an agency of the United States Government. Neither the United States Government nor any agency thereof, nor any of their empioyees, makes any warranty, express or implied, or assumes any legal liability or responsibility for the accuracy, completeness, or usefulness of any information, apparatus, product, or process disclosed, or represents that its use would not infringe privately owned rights. Reference herein to any specific commercial product, process, or service by trade name, trademark, manufacturer, or otherwise does not necessarily constitute or imply its endorsement, recommendation, or favoring by the United States Government or any agency thereof. The views and opinions of authors expressed herein do not necessarily state or reflect those of the United States Government or any agency thereof. 


\section{DISCLAIMER}

Portions of this document may be illegible electronic image products. Images are produced from the best available original document. 
and test results are given in detail in reports filed with Technical Information Data Forms in the Yucca Mountain Project records. These references are given in Table 1 .

TABLE 1. REFERENCES FOR DETAIED DISCUSSIONS OF TEST METHODS AND RESULTS

\begin{tabular}{|l|l|}
\hline \multicolumn{1}{|c|}{ Subject/Location } & \multicolumn{1}{|c|}{ Reference } \\
\hline Thermal Properties: Single Heater Test Area & TDIF 305593 \\
\hline Mechanical Properties: Single Heater Test Area & TDIF 305602 \\
\hline Thermal Properties: Drift Scale Test Area & TDIF 306127 \\
\hline Mechanical Properties: Drift Scale Test Area & TDIF 306126 \\
\hline Thermal Properties: Blocks from Alcoves 5 and 7 & TDIF 306294 \\
\hline Thermal Properties: Surface Drillholes & Brodsky et al. (1997), DOE (1996) \\
\hline Mechanical Properties: Surface Drillholes & $\begin{array}{l}\text { DOE (1996) summarizes results of several individual SAND } \\
\text { reports. }\end{array}$ \\
\hline
\end{tabular}

\section{SAMPLE ACQUISITION AND SPECIMEN PREPARATION}

Figure 1 is a plan view of Alcove 5 and shows the locations of the SHT and DST test areas. Each in situ field test required the production of boreholes to house instrumentation for measurements of temperature, rock displacement, and moisture concentration. Rock cores were recovered from these instrumentation boreholes and manufactured into test specimens for thermal and mechanical laboratory tests. An additional series of 5 blocks were recovered from Alcove 5 for testing and a large block was collected from Alcove 7.

The DST test area is a $5-\mathrm{m}$ diameter heated drift approximately $48 \mathrm{~m}$ long. The boreholes that were used for sample recovery are labeled MPBX1, MPBX2, MPBX3, and HDFR1 in Figure 1. HDFR1 extended vertically downward approximately $30 \mathrm{~m}(100 \mathrm{ft})$. Sampling was performed at evenly spaced intervals of $6 \mathrm{~m}$ as core availability permitted. The SHT test area shown in Figure 1 is a block of welded tuff approximately $13 \mathrm{~m}$ wide, 10 $\mathrm{m}$ long, and $5 \mathrm{~m}$ high. A $4 \mathrm{~kW}$ power heater was installed in a horizontal borehole located in the approximate center of the block and parallel to the Access Observation Drift. Sample material was recovered from 6 boreholes located within the SHT block.

All test specimens were right circular cylinders that were prepared and tracked according to SNL-YMP procedures. Specimen dimensions are given in Table 2. The test matrix and specimen moisture contents at the start of testing are given in Table 3. Some specimens were tested 'as-is', or in the air-dried state. For these specimens no effort made to preserve or alter the moisture content; however, the moisture contents are not representative of in situ conditions. After recovery from the ESF, these cores may have dried out at the Sample Management Facility at the Nevada Test Site. They were then machined into specimens using water as a coolant, and then they dried out somewhat in the laboratory until testing. Oven-dried specimens were dried at $105^{\circ}$ to constant mass and saturated specimens were saturated with distilled water under vacuum until mass stabilized.

TABLE 2. NOMINAL DIMENSIONS OF TEST SPECIMENS

\begin{tabular}{|l|c|c|c|c|c|}
\hline & $\begin{array}{c}\text { Thermal } \\
\text { Conductivity } \\
\text { (SHT and Alcove 5 and 7 Blocks) }\end{array}$ & $\begin{array}{c}\text { Thermal } \\
\text { Conductivity } \\
\text { (DST) }\end{array}$ & $\begin{array}{c}\text { Thermal } \\
\text { Expansion } \\
\text { (All) }\end{array}$ & Mechanical & Mechanical \\
(DST) & (SHT) \\
\hline Length $(\mathrm{m})$ & 0.0127 & 0.0127 & 0.0508 & 0.0762 & 0.1016 \\
\hline Diameter $(\mathrm{m})$ & 0.0508 & 0.0381 & 0.0254 & 0.0381 & 0.0419 \\
\hline
\end{tabular}


TABLE 3. TEST MATRIX

\begin{tabular}{|c|c|c|c|c|}
\hline & SHT & DST & Additional Alcove 5 Blocks & Alcove 7 Block \\
\hline $\begin{array}{l}\text { Mechanical Properties (unconfined } \\
\text { compression, elastic moduli) } \\
\text { Number of Tests: } \\
\text { Moisture Content: }\end{array}$ & $\begin{array}{r}22 \\
\text { As-is }^{(a)} \\
\end{array}$ & $\begin{array}{c}16 \\
\text { As-is } \\
\text { (a) } \\
\end{array}$ & 0 & 0 \\
\hline $\begin{array}{r}\text { Thermal Conductivity } \\
\qquad \begin{array}{r}\text { Number of Tests: } \\
\text { Moisture Content: }\end{array}\end{array}$ & $\begin{array}{c}4 \\
\text { As-is }^{(a)}\end{array}$ & $\begin{array}{c}20 \\
\text { Saturated }\end{array}$ & $\begin{array}{c}20 \\
\text { Oven-Dried }\end{array}$ & $\begin{array}{c}20 \\
\text { Oven-Dried }\end{array}$ \\
\hline $\begin{array}{l}\text { Number of Tests: } \\
\text { Moisture Content: }\end{array}$ & $\begin{array}{c}9 \\
\text { As-is }^{(a)}\end{array}$ & $\begin{array}{r}17 \\
\text { As-is } \\
\text { (a) }\end{array}$ & $\begin{array}{c}20 \\
\text { Oven-Dried }\end{array}$ & $\begin{array}{c}20 \\
\text { Oven-Dried }\end{array}$ \\
\hline
\end{tabular}

(a) No effort was made to preserve or alter the moisture content; however, the moisture contents are not representative of in situ conditions.

\section{TEST PROCEDURES}

\section{Mechanical Tests}

Unconfined compression tests were performed at room temperature. The specimens were placed in a flexible jackets to maintain constant moisture content during testing and to contain the specimen fragments during failure. Ports were cut out of the jackets at the requisite locations to accommodate axial and lateral deformation gages. Axial and radial displacements were measured using Linear Variable Displacement Transformers (LVDTs) in direct contact with the specimen. Specimens were loaded at a constant strain rate of $10^{-5} \mathrm{~s}^{-1}$ until peak force was reached.

Strains were calculated by dividing the measured axial and lateral displacements by the original gage separations. The axial gage consisted of two LVDTs, and the average axial strain is reported. Peak stress is the unconfined compressive strength and is obtained by dividing the peak force by the original cross-sectional area of the specimen. The static elastic constants were calculated by performing linear least squares fits to the data collected between 10 and $50 \%$ of the stress difference at failure. Young's modulus and Poisson's ratio are the slopes of the linear fits to the axial strain versus axial stress data, and the axial strain versus lateral strain data, respectively. Validation tests were performed regularly using specimens of 6061 aluminum.

\section{Thermal Conductivity}

Thermal conductivity measurements were made using the guarded heat flow meter (GHFM) method. The test specimen was located between two heater plates controlled at different temperatures, producing heat flow through the specimen. The heat flow was measured by a heat flux transducer (HFT) located between the specimen and one heater plate. Radial heat flow losses were minimized by surrounding the specimen with a cylindrical guard heater that was maintained near the mean specimen temperature, and by using specimens with lengths less than $20 \mathrm{~mm}$.

The GHFM is calibrated by comparing results obtained using specimens of known thermal conductivity with theoretical values. A single calibration is performed to determine both the contact resistance between the specimen and heater plates, and the proportionality constant relating the output of the heat flux transducer to the actual heat flux. Calibrations were performed on reference samples of Pyrex 7740. A range of thermal resistance values was obtained using specimens of different thickness $(6 \mathrm{~mm}, 9 \mathrm{~mm}, 12 \mathrm{~mm}, 15 \mathrm{~mm}$, and $18 \mathrm{~mm})$. Calibrations were verified by performing measurements on reference specimens of high-purity fused quartz. Recommended thermal conductivity values for Pyrex 7740 and high purity fused quartz are published by the National Institute of Standards and Technology (NIST). Verifications were performed periodically throughout the testing program. 

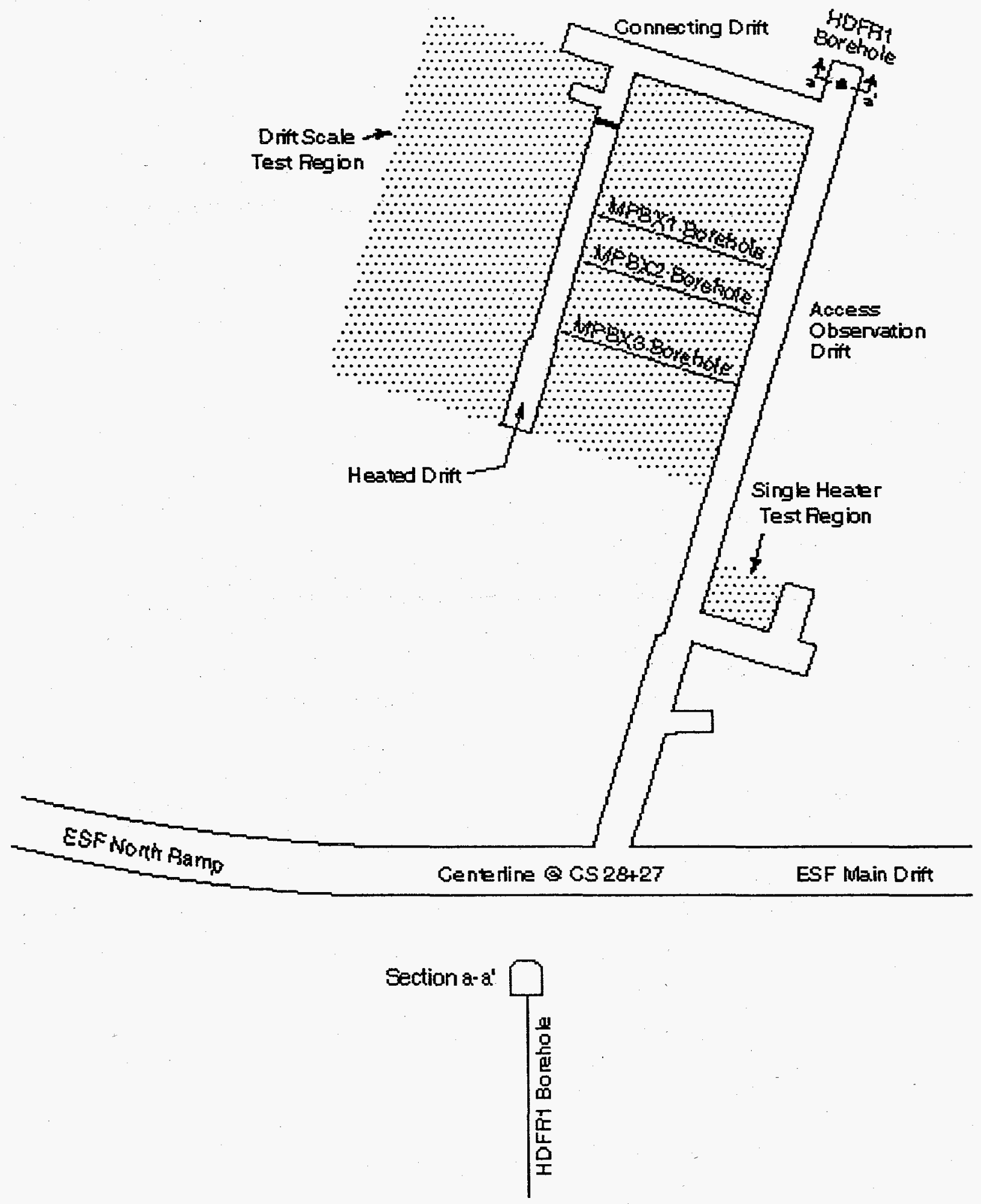

Tr-608058

Figure 1. Plan view of Drift Scale Test area. 
Once the instrument was calibrated, the test specimens were tested in the same manner as the reference materials. Data were obtained after the instrument had reached steady state thermal equilibrium. Saturated rocks were tested within moisture containment cells and thermal conductivities were measured up to only $70^{\circ} \mathrm{C}$. The SHT characterization tests were conducted up to $325^{\circ} \mathrm{C}$, and specimens from the additional site in Alcove 5 were tested to $200^{\circ} \mathrm{C}$.

\section{Thermal Expansion}

All of the thermal expansion data were obtained from experiments using one of two identical push-rod dilatometer instruments. The push-rod dilatometer is one of several instruments for measuring the linear coefficient of thermal expansion of materials. The specimen is placed in a receptacle at the end of a tube made of fused silica. A fused silica push rod is spring loaded against the specimen. A cylindrical furnace slides over the tube or specimen holder such that the specimen is positioned near the center of the furnace. As the temperature of the specimen changes, its length changes and this motion is transmitted by the push rod to a linear variable differential transformer (LVDT) located outside of the heated area. A type $\mathrm{K}$ thermocouple near the surface of the specimen monitors specimen temperature. The furnace temperature was ramped at a constant rate of $1^{\circ} \mathrm{C}$ per minute. Displacement and temperature data were acquired continuously throughout the heat-up and cool-down phases of the test and recorded by a computerized data acquisition system. Thermal expansions were measured between room temperature and $325^{\circ} \mathrm{C}$.

The dilatometer system expansion was calibrated and then verified by running Standard Reference Materials (SRMs) traceable to NIST and comparing data with expected results. Calibration was performed using a specimen of fused silica (SRM, 739), and verification was provided by measuring the expansion of SRM 731 (borosilicate glass) and SRM 738 (stainless steel). Verifications were performed regularly throughout the testing program.

The mean coefficient of thermal expansion ( $\bar{\alpha}$ or MCTE) is the linear thermal expansion per unit change in temperature. It was calculated in $25^{\circ} \mathrm{C}$ intervals by performing a linear least square regression to the temperature versus strain data over the interval. The slope of the linear fit provided values of $\alpha$.

\section{RESULTS}

\section{Mechanical Tests}

Table 4 provides a summary of mechanical properties data obtained for the DST and SHT areas and for specimens from the Tptpmn lithostratigraphic unit recovered from surface drillholes at the proposed repository. It should be noted that two testing laboratories were used. The DST characterization was performed by Sandia National Laboratories whereas all other tests were performed by New England Research Inc. The test procedures used were nominally identical. Also note that all of the surface drillhole specimen axes were vertical in situ whereas all of the SHT specimens and 12 of the 16 DST specimens had horizontal axes. Unconfined compressive strengths are lower, on average, for the SHT than for rocks from surface boreholes. Strengths determined for the DST are on the lower side of the expected range; however, the standard deviations for the compressive strengths are large. It was expected that measured strengths would be higher for the SHT and DST areas because the test specimens were not saturated. The lower strength values for the SHT and DST may be related to anisotropy. As noted previously, these specimen axes were primarily horizontal. The results show that with respect to Young's modulus, the DST specimens are slightly stiffer than other rocks from the site while the SHT moduli are generally on the lower side of the expected values. DST values for Poisson's ratio are typical; however, SHT values are slightly less than expected.

The lower strength values obtained for the SHT and DST areas would indicate that this is not the most favorable location within the repository for construction. It is therefore a very suitable location for a field test because 
problems may arise in this area that would not arise in other parts of the repository. The large variations in Young's modulus and Poisson's ratio for the DST and SHT also indicate that construction in this region may be more challenging than in other parts of the repository.

\section{TABLE 4. MECHANICAL DATA FROM SINGLE HEATER AND DRIFT SCALE TEST AREAS AND FROM SURFACE DRILLHOLES}

\begin{tabular}{|c|c|c|c|c|c|c|c|c|c|c|c|}
\hline \multirow[t]{2}{*}{$\begin{array}{l}\text { Test Region/ } \\
\text { Drillhole }\end{array}$} & \multirow[t]{2}{*}{ Axis } & \multirow[t]{2}{*}{$\begin{array}{c}\text { Moisture } \\
\text { Content }\end{array}$} & \multicolumn{3}{|c|}{$\begin{array}{l}\text { Unconfined Compressive } \\
\text { Strength (MPa) }\end{array}$} & \multicolumn{3}{|c|}{ Young's Modulus (GPa) } & \multicolumn{3}{|c|}{ Poisson's Ratio } \\
\hline & & & Mean & $\begin{array}{l}\text { Standard } \\
\text { Deviation }\end{array}$ & $\begin{array}{l}\text { No. of } \\
\text { Tests }\end{array}$ & Mean & $\begin{array}{l}\text { Standard } \\
\text { Deviation }\end{array}$ & $\begin{array}{l}\text { No. of } \\
\text { Tests }\end{array}$ & Mean & $\begin{array}{l}\text { Standard } \\
\text { Deviation }\end{array}$ & $\begin{array}{l}\text { No. of } \\
\text { Tests }\end{array}$ \\
\hline SHT & Horiz. & As-is & 143.2 & 50.3 & 22 & 32.4 & 2.9 & 22 & 0.17 & 0.02 & 22 \\
\hline DST & $\begin{array}{l}12 \text { Horiz. } \\
4 \text { Vert. }\end{array}$ & As-is & 176.4 & 65.8 & 16 & 36.8 & 3.5 & 16 & 0.20 & 0.04 & 16 \\
\hline NRG-5 & Vert. & Saturated & 173.3 & 99.4 & 8 & 32.5 & 10.8 & 8 & 0.20 & 0.06 & 8 \\
\hline NRG-6 & Vert. & Saturated & 193.0 & 55.7 & 8 & 32.1 & 3.0 & 8 & 0.19 & 0.03 & 8 \\
\hline NRG-7/7A & Vert. & Saturated & 192.1 & 51.1 & 9 & 33.2 & 4.2 & 19 & 0.22 & 0.03 & 19 \\
\hline SD-9 & Vert. & Saturated & 189.1 & 64.8 & 7 & 32.8 & 5.1 & 15 & 0.21 & 0.02 & 15 \\
\hline SD-12 & Vert. & Saturated & 195.8 & 3.5 & 2 & 34.3 & 2.0 & 4 & 0.20 & 0.01 & 4 \\
\hline
\end{tabular}

\section{Thermal Conductivity}

Thermal conductivity data for three temperatures are summarized in Table 5 for specimens from the Tptpmn lithostratigraphic unit. These data show that at low temperatures $\left(30^{\circ} \mathrm{C}\right)$ a small amount of anisotropy may be indicated for Alcove 5 at both dry and saturated conditions. Average thermal conductivities for vertical specimens are $0.1 \mathrm{~W} / \mathrm{mK}$ lower than for horizontal specimens, which is approximately the accuracy of the measurement. At elevated temperature $\left(200^{\circ} \mathrm{C}\right)$ these data show no significant lateral variability or anisotropy.

The data in Table 5 show that saturation state has a very significant effect on thermal conductivity. The SHT data were modeled (TDIF 306548) using a matrix permeability model, a low permeability model, and a high permeability model. The results and measured data are shown in Figure 2. This figure shows the influence of thermal conductivity values on predicted results. Values of $1.67 \mathrm{~W} /(\mathrm{mK})$ and $2.1 \mathrm{~W} /(\mathrm{mK})$ were used for dry and saturated thermal conductivities, respectively. For temperatures below $96^{\circ} \mathrm{C}$ (the boiling point of water at the SHT elevation) the rock is saturated and so all the models use a thermal conductivity value of $2.1 \mathrm{~W} /(\mathrm{mK})$. The three models all give very comparable results, indicating that conduction is the primary mechanism for heat transfer predicted in this region. At more elevated temperatures, the thermal conductivity for the matrix permeability model remains at $2.1 \mathrm{~W} /(\mathrm{mK})$ because the permeability is so low that water cannot boil off and the rock remains saturated. For the high permeability model, the water boils off and the conductivity goes to $1.67 \mathrm{~W} /(\mathrm{mK})$. The low permeability model is an intermediate condition between the other two models. At temperatures below $96^{\circ} \mathrm{C}$ (radial distances greater than $1.2 \mathrm{~m}$ ) the models overpredict the measured temperature by as much as about $5^{\circ} \mathrm{C}$. One means of correcting this overprediction would be to increase the saturated thermal conductivity value. 
TABLE 5. THERMAL CONDUCTIVITIES OF TPTPMN SPECIMENS FROM SINGLE HEATER AND DRIFT SCALE TEST AREAS AND FROM SURFACE DRILLHOLES

\begin{tabular}{|c|c|c|c|c|c|c|c|c|c|c|c|}
\hline \multirow{2}{*}{$\begin{array}{r}\text { Test Region/ } \\
\text { Drillhole }\end{array}$} & \multirow[t]{2}{*}{ Axis } & \multirow{2}{*}{$\begin{array}{l}\text { Moisture } \\
\text { Content }\end{array}$} & \multicolumn{3}{|c|}{$30^{\circ} \mathrm{C}$} & \multicolumn{3}{|c|}{$70^{\circ} \mathrm{C}$} & \multicolumn{3}{|c|}{$200^{\circ} \mathrm{C}$} \\
\hline & & & $\begin{array}{c}\text { Mean }^{(0)} \\
(\mathrm{W} / \mathrm{mK})\end{array}$ & \begin{tabular}{|l|} 
Standard \\
Deviation \\
(W/mK)
\end{tabular} & $\begin{array}{c}\text { No. of } \\
\text { Measure- } \\
\text { ments }\end{array}$ & $\begin{array}{l}\text { Mean }^{(\mathrm{b})} \\
(\mathrm{W} . / \mathrm{mK})\end{array}$ & $\begin{array}{l}\text { Standard } \\
\text { Deviation } \\
\text { (W/mK) }\end{array}$ & $\begin{array}{c}\text { No. of } \\
\text { Measure- } \\
\text { ments }\end{array}$ & $\begin{array}{l}\text { Mean }^{(\mathrm{b})} \\
(\mathrm{W} / \mathrm{mK})\end{array}$ & $\begin{array}{l}\text { Standard } \\
\text { Deviation } \\
(\mathrm{W} / \mathrm{mK})\end{array}$ & $\begin{array}{c}\text { No. of } \\
\text { Measure- } \\
\text { ments }\end{array}$ \\
\hline Alcove 5 Blocks & Horiz. & Dry & 1.7 & 0.1 & 5 & 1.6 & $<0.05$ & 5 & 1.7 & $<0.05$ & 5 \\
\hline Alcove 5 Blocks & Vert. & Dry & 1.6 & 0.1 & 5 & 1.6 & $<0.05$ & 5 & 1.7 & 0.1 & 5 \\
\hline Alcove 7 Block & Horiz. & Dry & 1.6 & 0.1 & 5 & 1.6 & $<0.05$ & 5 & 1.7 & $<0.05$ & 5 \\
\hline Alcove 7 Block & Vert. & Dry & 1.6 & $<0.05$ & 5 & 1.6 & $<0.05$ & 5 & 1.7 & $<0.05$ & 5 \\
\hline SHT & Horiz. & As-is & 1.6 & 0.2 & 4 & 1.6 & 0.2 & 4 & 1.7 & 0.1 & 4 \\
\hline DST & Horiz. & Sat. & 2.1 & 0.1 & 15 & 2.1 & 0.1 & 15 & - & - & - \\
\hline DST & Vert. & Sat. & 2.0 & 0.1 & 4 & 2.1 & 0.1 & 4 & - & - & - \\
\hline
\end{tabular}

(a) Sat. implies vacuum saturated; see text for explanation of 'as-is'

(b) Accuracy of measurement is approximately $\pm 1 \mathrm{~W} / \mathrm{mK}$. More specific information on errors for each test location are given in the original data sources.

Temperature vs. Radial Distance After 266 Days of Heating

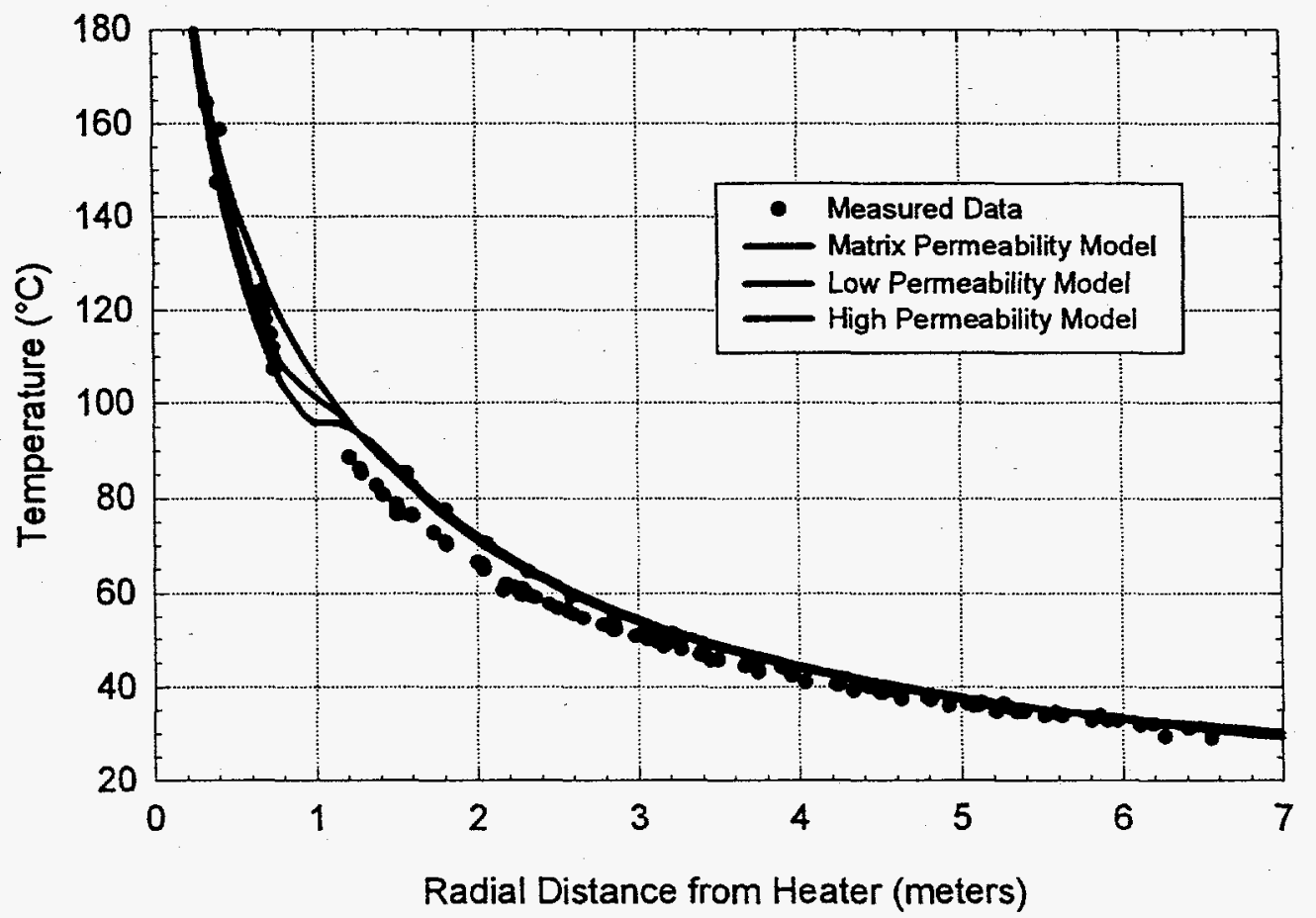

Figure 2. Radial temperature distribution in the vertical plane that intersect the heater at its midpoint, after 266 days of heating the Single Heater Test Area (TDIF 306548)

\section{Thermal Expansion}

MCTEs calculated for 17 specimens from the DST area are shown as a function of temperature in Figure 3. Initial MCTE values are generally between $5 \mu \varepsilon /{ }^{\circ} \mathrm{C}$ and $10 \mu \varepsilon /{ }^{\circ} \mathrm{C}$ and increase with temperature. Up through the interval of $150-175^{\circ} \mathrm{C}$, all MCTEs are below $15 \mu \varepsilon /{ }^{\circ} \mathrm{C}$. At approximately $175-225^{\circ} \mathrm{C}$ the range of MCTEs sharply increases. One specimen, HDFR1-97.9 shows very little change in MCTE with increasing temperature. This 
specimen was from the vertical borehole (HDFR1) and may have come from within the upper part of the Tptpll (lower lithophysal) unit. The remaining specimens all show steep increases in MCTE beginning at approximately $200^{\circ} \mathrm{C}$ and continuing until approximately $300^{\circ} \mathrm{C}$. This steep increase is attributed to phase changes in the silica mineral phases of crystobalite and tridymite. The MCTEs calculated over the temperature interval of $300-325^{\circ} \mathrm{C}$ decrease as the phase change is completed. Two specimens, MPBX2-85.0 and MPBX1-40.4 show evidence of the phase change beginning at $175^{\circ} \mathrm{C}$ as would be expected for rocks containing tridymite. X-ray diffraction analyses of the rock shells from which the specimens were taken indicated the presence tridymite in only two specimens. MPBX1-40.4 contained 7\% tridymite (Roberts and Viani, 1997); however, the rock shell corresponding to MPBX2-85.0 showed no detectable tridymite while the shell corresponding to MPBX1-21.0, which is within the main trend of the thermal expansion data, comprised $3-4 \%$ tridymite. Most rocks contained $20-30 \%$ crysobalite. Specimen HDFR1-97.9 was the only specimen that contained only $4 \%$ crystobalite. These data show that phase changes in the rock cause significant increases in CTEs above $200^{\circ} \mathrm{C}$. The presence of tridymite, though not ubiquitous in the DST area, can cause significant changes in CTE below $200^{\circ} \mathrm{C}$.

Mean values of thermal expansion coefficients from the DST and SHT test characterizations, from Alcove 5 and 7 blocks, and from surface drillhole laboratory data for the Tptpmn are compared in Figure 4. Only 16 DST specimens were used because HDFR1-97.9, which may have come from a different lithostratigraphic unit, was omitted. For temperatures over $150^{\circ} \mathrm{C}$, DST values are consistently higher than those for other locations. This is attributed to the presence of tridymite in the DST region. The higher MCTEs obtained for the DST as compared with other locations within the proposed repository indicate that difficulties may arise in this location that are not typical. The thermal expansion data therefore indicate that this is a suitable location for an in situ field test.

Coefficients of thermal expansion measured on oven-dried specimens from Alcove 5 and 7 blocks are compared in TDIF 306294 to assess lateral variability and anisotropy. Some aspects of these data are summarized here. Below $200^{\circ} \mathrm{C}$, during the first heating cycle, there are no significant differences in MCTEs due to either lateral variability or anisotropy. Some lateral variability is evident during the first heating cycle at temperatures above $300^{\circ} \mathrm{C}$, and some anisotropy (approximately $4 \mu \mathrm{\varepsilon} /{ }^{\circ} \mathrm{C}$ ) is evident in Alcove 7 at temperatures above $250^{\circ} \mathrm{C}$ (see Figure 5).

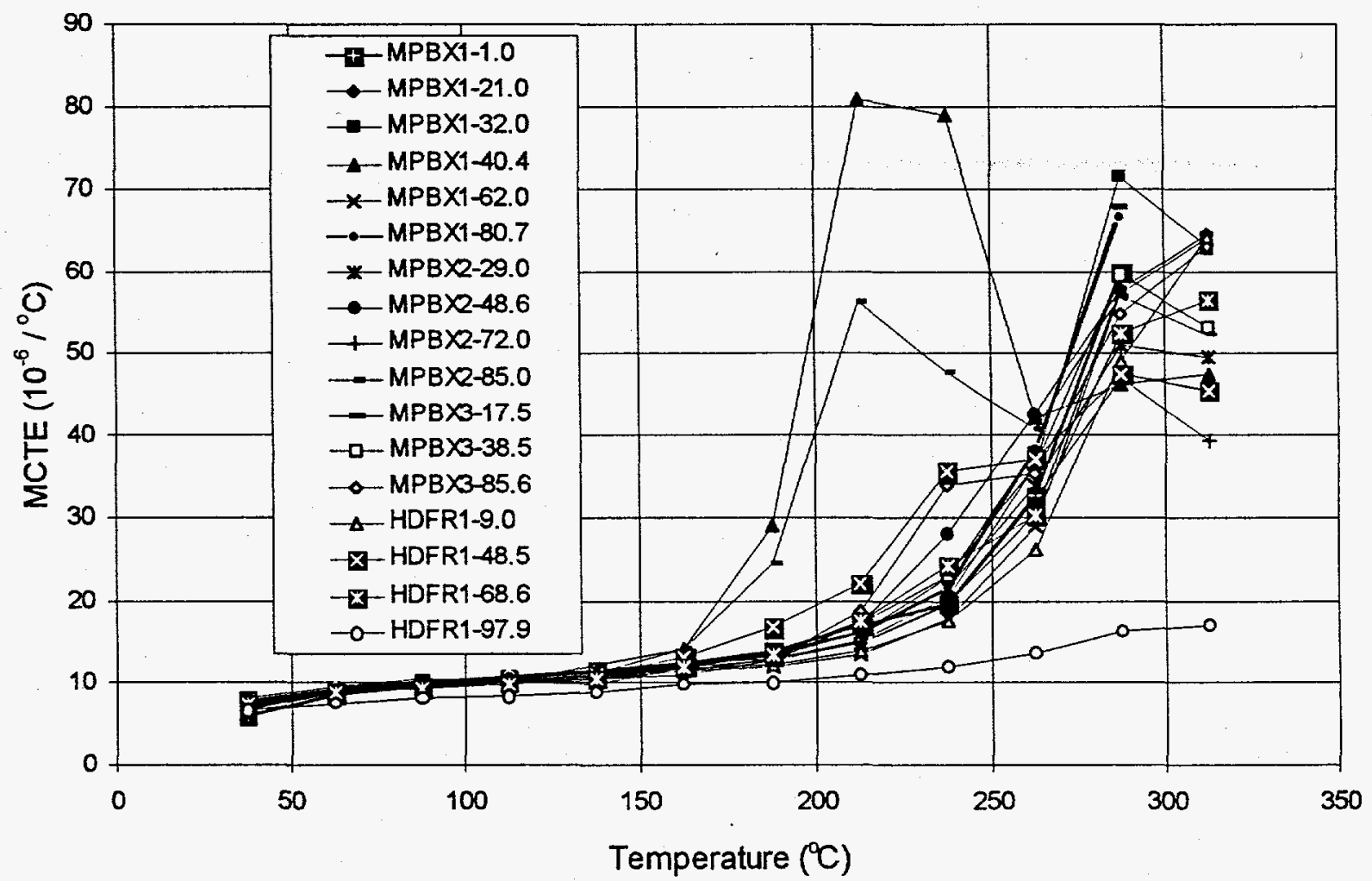

Figure 3. Mean coefficients of thermal expansion-versus-temperature for DST specimens. 


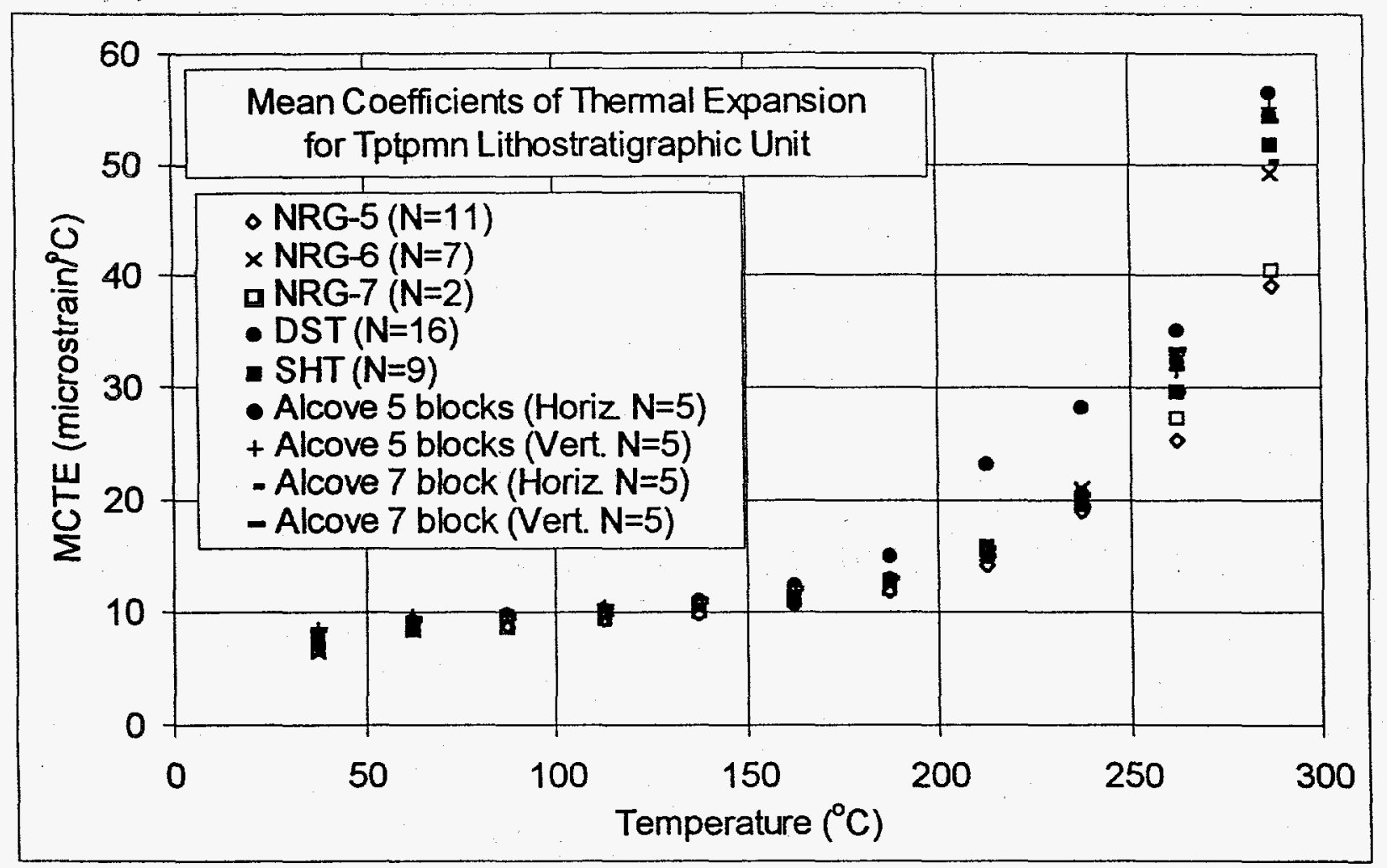

Figure 4. Mean Coefficients of Thermal Expansion (MCTEs) and Standard Deviations Obtained During First Heating Cycle in Laboratory Tests for Specimens from Several Locations. Average values are plotted; the numbers of tests used to determine each average value are given in the legend.

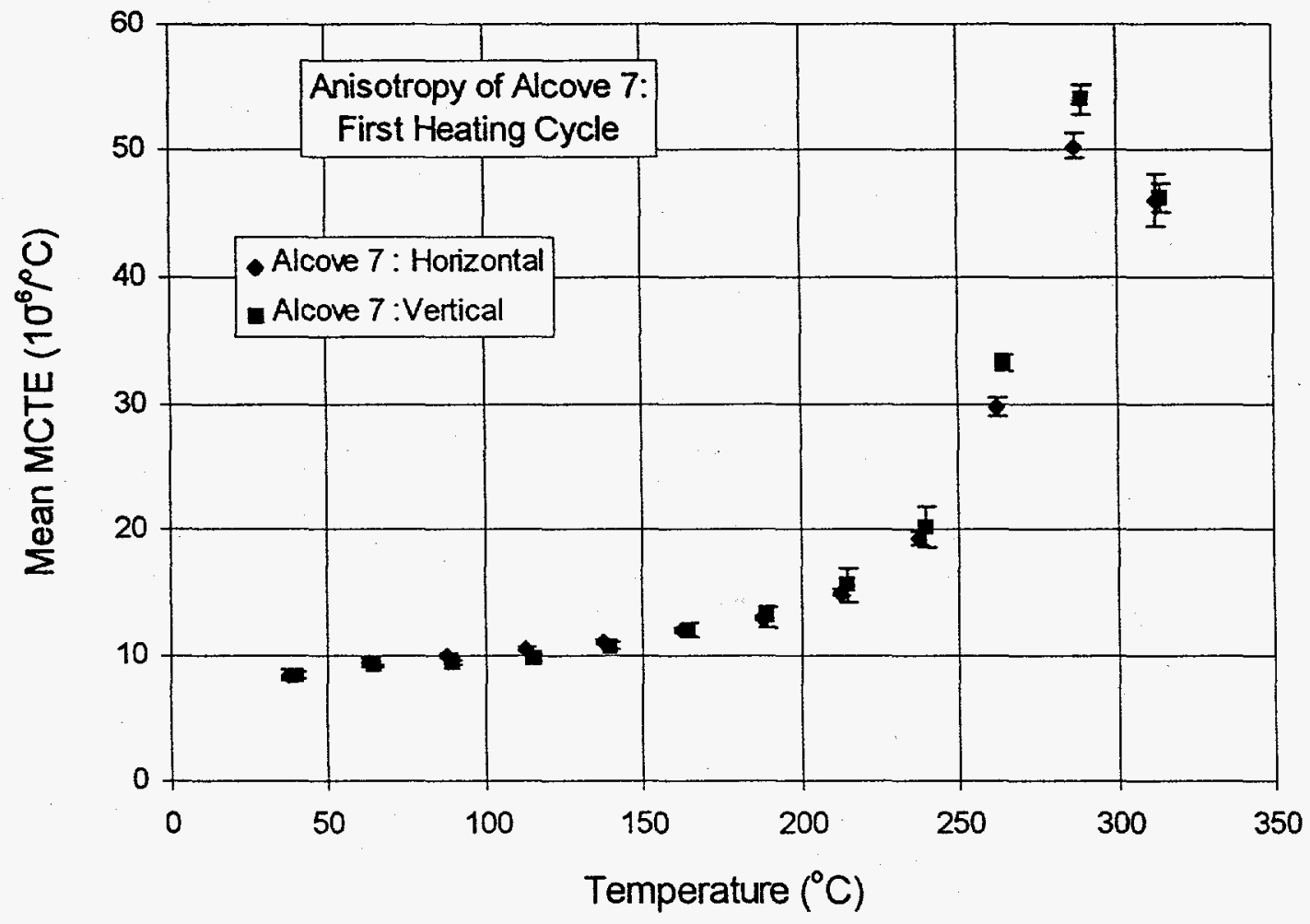

Figure 5. Qualitative assessment of anisotropy in thermal expansion between vertical and horizontal specimens, during the first heating of specimens from Alcove 7. 
Laboratory thermal and mechanical tests were conducted on specimens taken from the ESF at Yucca Mountain. Unconfined compression tests, thermal expansion tests, and thermal conductivity tests were used to characterize the rock volumes affected by the SHT and DST in situ heating experiments. Thermal properties measurements were made on additional blocks taken from Alcoves 5 and 7. Unconfined compressive strengths are lower for the SHT than for other parts of the repository. Strengths determined for the DST are on the lower side of the expected range; however, the standard deviations for the compressive strengths are large. The lower strength values for the SHT and DST may be related to anisotropy. The axes of test specimens from surface drillholes were vertical whereas the SHT and most of the DST specimens were horizontal. Young's moduli for the DST specimens are slightly higher than for other rocks from the repository site, while moduli for SHT specimens are generally on the lower side of the expected values. DST values for Poisson's ratio are typical; however, SHT values are slightly less than expected. Thermal conductivities are very consistent throughout Alcove 5 and are closely matched to the values obtained from one block of Alcove 7 rock. Some anisotropy in thermal conductivity may be evident in Alcove 5 at low temperatures. Thermal expansion coefficients are higher for the DST rocks than for the other sites. This is attributed to the presence of tridymite and affects MCTEs below $200^{\circ} \mathrm{C}$. The mechanical and thermal expansion data suggest that Alcove 5 is a suitable location for an in situ field test. No comparisons are made at this time between Alcove 5 thermal conductivity data and data obtained from other parts of the proposed repository.

\section{REFERENCES}

Brodsky, N.S., M. Riggins, J. Connolly, and P. Ricci. 1997. Thermal Expansion, Thermal Conductivity, and Heat Capacity Measurements for Boreholes UE25 NRG-4, UE25 NRG-5, USW NRG-6, and USW NRG-7/7A. SAND951955. Albuquerque, NM: Sandia National Laboratories.

Department of Energy (DOE). 1996. Civilian Radioactive Waste Management System: Management and Operating Contractor. Yucca Mountain Site Geotechnical Report. BAAA00000-01717-4600-00065 REV 00. Las Vegas, NV: Yucca Mountain Site Characterization Project.

Roberts, S. and B. Viani. 1997. Mineral abundances for Samples from Instrumentation Boreholes in the Access Drift Scale Test Area (DST) of the ESF.

TDIF 305593. 1996. "Thermal Properties of Test Specimens from the Single Heater Test Area in the Thermal Testing Facility at Yucca Mountain, Nevada." Data Tracking Number: SNL22080196001.001.

TDIF 305602. 1996. "Unconfined Compression Tests on Specimens from the Single Heater Test Area in the Thermal Testing Facility at Yucca Mountain, Nevada." Data Tracking Number: SNL22080196001.002.

TDIF 306126. 1997. "Unconfined Compression Tests on Specimens from the Drift Scale Test Area of the Exploratory Studies Facility at Yucca Mountain, Nevada." Data Tracking Number: SNL2210019696001.001.

TDIF 306127. 1997. "Thermal Expansion and Thermal Conductivity of Test Specimens fro the Drift Scale Test Area of the Exploratory Studies Facility at Yucca Mountain, Nevada." Data Tracking Number: SNL22100196001.001.

TDIF 306294. 1997. "Laboratory Measurements of Thermal Expansion and Thermal Conductivity for Specimens from Alcoves 5 and 7 of the Exploratory Studies Facility and from SD Drillholes at Yucca Mountain, Nevada." Data Tracking Number: SNL22100196001.002.

TDIF 306548 "Evaluation and Comparative Analysis of Single Heater Test Thermal and Thermomechanical Data: First Quarter FY98 Results." Data Tracking Number: SNF38040197001.001. 